\title{
PENYELESAIAN PERKARA VERZET MELALUI TEKNIK ALTERNATIF DISPUTE RESOLUTION (ADR)
}

\author{
Ladin \\ Institut Agama Islam Negeri (IAIN) Tulungagung \\ J1. Mayor Sujadi Tim. No.46, Plosokandang, Kedungwaru, Kabupaten Tulungagung, \\ Jawa Timur 66221 \\ Email: Abahzahro@gmail.com
}

\begin{abstract}
The court is a tool provided by the state to resolve disputes between subjects of law in a particular society in order to get a justice, which included a principle of simple,fast and cost ringan,akan but in practice it is often difficult for these principles in the meet,because thefact of ist decision that produced in court requires a complicated process requiring a long timeand are winning one of the parties, the stletement is an alternative dispute resolusition institution or system for settling disputes or opinion through prosedures agreed upon by the partiesthe courtis a tool provided by the state to resolve diputesbetween (ADR) comes with flexibility properties offering solutions institusion or system for settling disputes or opinion through prosedures agreed upon bythe parties.
\end{abstract}

Keywords : Verzet, Aternative Dispute Resolution (ADR)

\begin{abstract}
ABSTRAK
Pengadilan merupakan sarana yang disediakan oleh negara untuk menyelesaikan sengketa antar subyek hukum dalam masyarakat tertentu guna mendapatkan suatu keadilan, yang mana didalamnya terdapat asas sederhana, cepat, dan biaya ringan. Akan tetapi dalam prakteknya seringkali asas tersebut sulit untuk ditemui, karena pada kenyataannya putusan yang dihasilkan di pengadilan memerlukan proses yang rumit, membutuhkan waktu yang panjang dan bersifat memenangkan salah satu pihak. Penyelesaian secara Alternative Dispute Resoluton (ADR) hadir dengan sifat fleksibelnya menawarkan solusi dimungkinkankannya sistem ini untuk diterapkan di lembaga pengadilan guna mengantisipasi hal-hal tersebut. ADR (Alternative Dispute Resolution) atau alternatif penyelesaian sengketa adalah lembaga atau sistem penyelesaian sengketa atau beda pendapat melalui prosedur yang disepakati para pihak.
\end{abstract}

Kata kunci : Perkara verzet, Alternatif Dispute Resolution (ADR) 


\section{A. PENDAhuluan}

\section{Latar Belakang Masalah}

Dalam roda kehidupan yang selalu berputar ini, manusia sebagai makhluk hidup senantiasa berhubungan satu dengan yang lainnya guna memenuhi segala kebutuhan hidupnya, baik itu kebutuhan akan pangan, sandang, tempat tinggal, kebebasan maupun kebutuhan akan suatu keadilan.

Keadilan merupakan salah satu kebutuhan dalam hidup manusia yang umumnya diakui di semua tempat di dunia ini. Apabila keadilan itu kemudian dikukuhkan kedalam suatu institusi yang bernama hukum, maka hukum itu harus mampu menjadi saluran agar keadilan itu dapat diselenggarakan secara seksama dalam masyarakat. Dalam konteks ini tugas hakim yang paling berat adalah menjawab kebutuhan manusia akan keadilan tersebut, sebab standar dan nilai rasa keadilan bagi kedua belah pihak yang bersengketa tentu berbeda.

Sedangkan yang namanya sengketa itu sendiri tidak dapat dilepaskan dari kehidupan manusia. Sepanjang kehidupannya manusia selalui diwarnai dengan sengketa. Dalam masyarakat yang tradisional sengketa kerap diselesaikan antar mereka dengan menggunakan kekerasan seperti perang. Sementara pada masyarakat modern menyelesaikan sengketa dilakukan tanpa kekerasan dengan memanfaatkan pihak ketiga yang dianggap netral.

Sebagian masyarakat tersebut ada juga yang menyelesaikan dan menyerahkan segala sengketa yang terjadi melalui jalur litigasi (pengadilan) maupun non litigasi (di luar pengadilan) seperti arbitrase, negosiasi, mediasi, konsiliasi dan bentuk alternatif penyelesaian sengketa lainnya.

Adapun pengadilan itu sendiri merupakan sarana yang disediakan oleh negara untuk menyelesaikan sengketa antar subyek hukum dalam masyarakat tertentu. Dalam sistem peradilan dikenal adanya asas sederhana, cepat dan biaya ringan. Tetapi dalam prakteknya, asas tersebut masih sulit untuk ditemui, baik di negara maju maupun di negara berkembang. Putusan 
pengadilan sering dirasakan tidak adil bagi pihak yang kalah, karena dalam proses persengketaan di pengadilan suasananya seringkali konfrontatif sehingga para pihak dihadapkan pada kenyataan menang atau kalah (win or lose). Hal ini mengakibatkan selalu ada upaya dari pihak yang kalah untuk menunda atau mencari peluang memenangkan perkara melalui berbagai upaya hukum antara lain naik banding, kasasi dan peninjauan kembali yang mana itu semua akan memakan waktu sangat lama bahkan dapat sampai puluhan tahun.

Berbagai upaya hukum tersebut pada dasarnya memang disediakan bagi mereka para pencari keadilan yang merasa tidak puas dengan suatu putusan yang dijatuhkan oleh hakim, tetapi tetap saja hal tersebut membuktikan lamanya berperkara dengan proses litigasi.

Masyarakat pada umumnya menyadari bahwasannya penyelesaian sengketa melalui badan peradilan memakan waktu lama dan sangat tidak efektif, serta berbelit-belit dalam proses penyelesaian perkaranya. Akan tetapi penyelesaian perkara melalui litigasi sulit dihilangkan, karena hampir semua perkara yang diputuskan kebanyakan dianggap belum memuaskan bagi para pihak yang bersengketa, yang mana kemudian mereka mengajukan upaya banding, kasasi bahkan peninjauan kembali, termasuk juga upaya hukum verzet atas suatu putusan verstek (putusan yang dijatuhkan pengadilan sebagai akibat dari ketidakhadiran tergugat/termohon selama pemeriksaan perkara. ${ }^{24}$ Bagi mereka yang merasa tidak menerima putusan verstek tersebut memang dapat dan disediakan baginya upaya hukum verzet. Hal ini berlandaskan pada pasal 129 ayat (1) HIR yang dinyatakan bahwa "Tergugat yang dihukum sedang ia tidak hadir (verstek) dan tidak menerima putusan itu, dapat memajukan atas keputusan itu. ${ }^{25}$

\footnotetext{
${ }^{24}$ Ropaun Rambe, Implementasi Hukum Islam, (Jakarta: Perca, 2001), hlm. 127.

${ }^{25}$ Lihat HIR Pasal 129 ayat (1)
} 
Adapun kesemua bentuk upaya hukum tersebut sudah menjadi kebiasaan yang menyebabkan terjadinya tumpukan perkara di Mahkamah Agung yang pada akhirnya menjadi tunggakan perkara dari tahun ke tahun. Hal itu disebabkan masyarakat pencari keadilan tidak lagi mempersoalkan apakah keputusan yang dijatuhkan oleh Pengadilan benar dan adil. Kekalahan dianggap ketidakadilan dan karenanya segala upaya yang dibenarkan oleh Undang-undang atau peraturan yang berlaku sedapat mungkin dimanfaatkan.

Salah satu langkah untuk menekan terjadinya penumpukan perkara dan mengatasi tunggakan perkara dari tahun ke tahun di Mahkamah Agung adalah dengan menerapkan lembaga damai, karena perkara atau sengketa yang diakhiri dengan perdamaian pada tingkat pertama sudah tertutup kemungkinan untuk upaya banding, kasasi dan peninjauan kembali.

Kemungkinan-kemungkinan untuk terjadinya perdamaian para pihak yang bersengketa selama berlangsung proses peradilan telah diatur dalam Pasal 16 ayat (2) Undang-Undang Nomor 4 Tahun 2004 tentang Kekuasaan Kehakiman yang isi pasalnya selengkapnya sebagai berikut :"Ketentuan dalam ayat (1) tidak menutup kemungkinan untuk usaha penyelesaian perkara perdata secara perdamaian". ${ }^{26}$

Usaha perdamaian khusus untuk perkara-perkara perdata dilakukan oleh Majelis (Hakim) yang memeriksa dan menyidangkan perkara yang bersangkutan serta dilaksanakan pada sidang pertama sebelum memasuki pemeriksaan pokok perkara sebagaimana dimaksud dalam Pasal 130 HIR/154 RBg yang isinya sebagai berikut :

${ }^{26}$ Undang-undang Republik Nomor. 4 Tahun 2004 Tentang Kekuasaan Kehakiman Disahkan melalui lembaran Negara Republik Indonesia Tahun 2004 Nomor 8 dan tambahan Lembaran Negara Negara Republik Indonesia Nomor 4358. 
Ayat (1) Bila pada hari yang telah ditentukan para pihak datang menghadap, maka pengadilan negeri dengan perantaraan ketua berusaha mendamaikannya.

Ayat (2) Bila dapat dicapai perdamaian, maka dalam sidang itu juga dibuatkan suatu akta dan para pihak dihukum untuk menaati perjanjian yang telah dibuat, dan akta itu mempunyai kekuatan serta dilaksanakan seperti suatu surat keputusan biasa.

Ayat (3) Terhadap suatu keputusan tetap semacam itu tidak dapat diajukan banding.

Untuk efektifitas Pasal tersebut diatas, maka dikeluarkan Surat Edaran Mahkamah Agung (SEMA) No. 1 Tahun 2002 Tentang Pemberdayaan Pengadilan Tingkat Pertama Menerapkan Lembaga Damai yang salah satu petunjuknya disebutkan "agar semua hakim (Majelis) yang menyidangkan perkara, dengan sungguh-sungguh mengusahakan perdamaian dengan menerapkan ketentuan Pasal 130 HIR/154 RBg tidak hanya sekedar formalitas menganjurkan perdamaian".

Khusus untuk perkara-perkara perceraian (baik dalam bentuk permohonan cerai talak maupun dalam bentuk gugatan cerai) pada Pengadilan Agama diatur dalam Pasal 65 dan 82 Undang-Undang No.7 Tahun 1989 Tentang Peradilan Agama yang isi pasal selengkapnya sebagai berikut : ${ }^{27}$

Pasal 65 Perceraian hanya dapat dilakukan di depan sidang pengadilan setelah pengadilan yang bersangkutan berusaha dan tidak berhasil mendamaikan kedua belah pihak.

Pasal 82 :

Ayat (1) Pada sidang pertama pemeriksaan gugatan perceraian, hakim berusaha mendamaikan kedua pihak.

Ayat (2) Dalam sidang perdamaian tersebut, suami istri harus datang secara pribadi, kecuali apabila salah satu pihak

${ }^{27}$ Undang-undang Repulik Indonesia Nomor 7 Tahun 1989 Tentang Peradilan Agama Disahkan melalui lembaran Negara Republik Indonesia Tahun 1989 Nomor 49 dan tambahan Lembaran Negara Negara Republik Indonesia Nomor 34000. 
bertempat kediaman di luar negeri, dan tidak dapat datang menghadap secara pribadi dapat diwakili oleh kuasanya yang secara khusus dikuasakan itu.

Ayat (3) Apabila kedua pihak bertempat kediaman di luar negeri, maka penggugat pada sidang perdamaian tersebut harus menghadap secara pribadi.

Ayat (4) Selama perkara belum diputuskan, usaha mendamaikan dapat dilakukan pada setiap sidang pemeriksaan.

Dengan berpatokan pada Pasal tersebut diatas, khusus untuk perkara perceraian maka pemeriksaan baru dapat dilaksanakan oleh majelis hakim setelah mereka tidak berhasil mendamaikan pihak-pihak yang bersengketa dan usaha perdamaian yang dilakukan tidak terbatas pada sidang pertama, akan tetapi pada setiap pemeriksaan atau persidangan tersebut sepanjang perkara yang bersangkutan belum diputus.

Salah satu kelemahan jika usaha perdamaian yang dilakukan oleh majelis hakim selama berlangsungnya persidangan adalah adanya keterbatasan dari segi waktu yang digunakan. Kelemahan itu pada akhirnya berpengaruh pada ketidakberhasilan upaya perdamaian para pihak yang bersengketa. Untuk itu dalam upaya mengoptimalkan usaha perdamaian para pihak yang bersengketa, maka Mahkamah Agung telah mengeluarkan SEMA Nomor 1 Tahun 2002, yang selanjutnya disempurnakan dengan adanya Peraturan Mahkamah Agung (PERMA) Nomor 2 Tahun 2003 Tentang Prosedur Mediasi di Pengadilan, yang mana didalamnya Mahkamah Agung mengambil langkah nyata dengan terobosan baru dalam sistem hukum di Indonesia dengan memakai bentuk mekanisme berperkara secara non litigasi atau disebut Alternative Dispute Resolution (ADR) ke dalam proses litigasi.

Mekanisme berperkara secara non litigasi atau ADR telah dilegitimasi melalui Undang-Undang Nomor 30 Tahun 1999 tentang Arbitrase dan Alternatif Penyelesaian Sengketa dalam pasal 1 ayat (10) yang isi selengkapnya sebagai berikut: "Alternatif Penyelesaian Sengketa adalah 
lembaga penyelesaian sengketa atau beda pendapat melalui prosedur yang disepakati para pihak, yakni penyelesaian sengketa di luar pengadilan dengan cara konsultasi, negosiasi, mediasi, konsiliasi dan penilaian ahli". ${ }^{28}$

ADR atau pilihan penyelesaian sengketa sebagai sarana penyelesaian sengketa non litigasi kini bukan saja mendapat perhatian dan minat bagi negara maju (modern) seperti Amerika Serikat dan Jepang, tetapi juga mendapat perhatian yang serius dari negara berkembang seperti di Indonesia.

Urgensi pelembagaaan ADR atau pilihan penyelesaian sengketa di Indonesia didasari beberapa fenomena adanya tuntutan masyarakat terhadap mekanisme sengketa yang mampu memenuhi rasa keadilan yang semakin hari semakin kabur, keinginan masyarakat untuk ikut serta secara aktif dan kritis dalam menyikapi berbagai permasalahan serta harapan untuk hasil yang samasama dapat diterima oleh semua pihak (win-win solution), sehingga dapat dihindari segala akibat yang tidak memberi kepuasan akan kebutuhan masyarakat terhadap rasa keadilan.

Adapun Pengambilan perkara Nomor 1187/Pdt.G/2005/PA mengenai cerai talak yang sampai pada upaya hukum verzet sebagai bahan penelitian disini adalah bukan tanpa pijakan, akan tetapi menurut para hakim yang memutus perkara dari sekian banyak perkara yang masuk di Pengadilan Agama, perkara tersebut merupakan perkara yang menarik untuk diteliti sehingga penulis disarankan untuk menelitinya dari segi penerapan ADR di dalam perkara tersebut.

Sedangkan urgensi penerapan Alternative Dispute Resolution (ADR) dalam penyelesaian perkara verzet bernomor 1187/Pdt.G/2005/PA adalah dapat meminimalisir penumpukan perkara di pengadilan agama tingkat pertama juga dapat mengantisipasi penumpukan perkara di pengadilan tingkat

${ }^{28}$ Undang-Undang Nomor 30 Tahun 1999 tentang Arbitrase dan Alternatif Penyelesaian Sengketa Disahkan melalui Lembaran Negara Republik Indonesia Tahun 1999 Nomor 138 dan tambahan Lembaran Negara Republik Indonesia Nomor 3872. 
selanjutnya sampai ke tingkat Mahkamah Agung. Sehingga memungkinkan kepada majelis hakim untuk memeriksa perkara yang tidak hanya berkisar pada perceraian saja, akan tetapi juga perkara-perkara lain yang menjadi wewenanang PA. Selain itu juga dapat menghilangkan atau menekan rasa dendam diantara Pelawan dan Terlawan yang dimungkinkan akan timbul dikemudian hari setelah terjadi adanya perceraian karena dilandasi perasaan yang tidak puas terhadap suatu putusan yang dijatuhkan.

\section{Rumusan Masalah}

Bagaimana penyelesaian perkara verzet melalui teknik Alternatif Dispute Resolution (ADR)

\section{Tujuan Penelitian}

Untuk mengkaji secara mendalam penyelesaian perkara verzet melalui teknik Alternatif Dispute Resolution (ADR)

\section{B. PEMBAHASAN}

\section{Konsep Dasar Perceraian}

a. Pengertian

Akad perkawinan dalam hukum Islam bukanlah perkara perdata semata, melainkan ikatan suci yang terkait dengan keyakinan dan keimanan kepada Allah. ${ }^{29}$ Dengan demikian ada dimensi ibadah dalam sebuah perkawinan. Untuk itu perkawinan harus dipelihara dengan baik sehingga bisa abadi dan apa yang menjadi tujuan perkawinan dalam Islam dapat terealisasi.

Namun seringkali apa yang menjadi tujuan perkawinan kandas di perjalanan. Perkawinan harus putus di tengah jalan. Sebenarnya putusnya perkawinan merupakan hal yang wajar saja, karena makna dasar dari

${ }^{29}$ Amiur Nuruddin dan Azhari Akmal Tarigan, Hukum Perdata Islam di Indonesia; Studi Kritis Perkembangan Hukum Islam dari Fikih, UU No. 1/1974 sampai KHI (Jakarta: Prenada Media, 2004), hlm. 206 
sebuah akad adalah ikatan yang konsekuensinya ia dapat lepas yang kemudian dapat disebut dengan talak. Makna dasar talak adalah melepaskan ikatan atau melepaskan perjanjian. ${ }^{30}$ Namun yang harus jadi catatan dan pijakan dalam perceraian adalah tata caranya. Dalam masalah perceraian, Islam mengajarkan kalau memang perceraian harus terjadi, maka harus di laksanakan secara ma'ruf, baik dan tidak ada unsur saling menyakiti sebagaimana difirmankan oleh Allah dalam kitab sucinya yang berbunyi : ${ }^{31}$

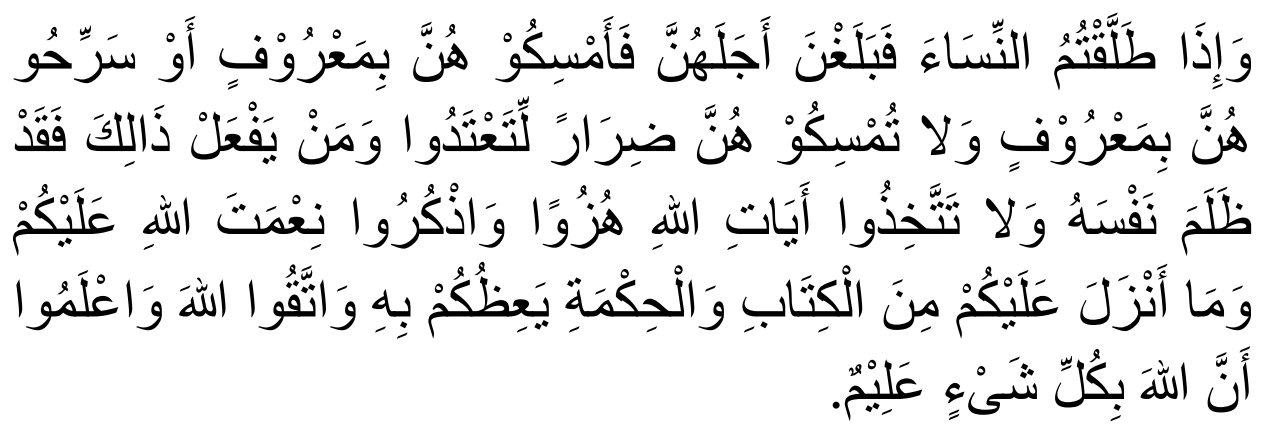

Artinya: Apabila kamu mentalak isteri-isterimu, lalu mereka mendekati akhir iddahnya, maka rujukilah mereka dengan cara yang ma'ruf, atau ceraikanlah mereka dengan cara yang ma'ruf (pula). Janganlah kamu rujuki mereka untuk memberi kemudharatan, karena dengan demikian kamu berbuat aniaya pada mereka. Barang siapa berbuat demikian, maka sesungguhnya ia telah berbuat dzalim terhadap dirinya sendiri. Janganlah kamu jadikan hukum-hukum Allah sebagai permainan. Dan ingatlah ni'mat Allah padamu, dan apa yang telah Allah turunkan kepadamu yaitu al-Kitab dan al-Hikmah. Allah memberi pengajaran kepadamu dengan apa yang diturunkan-Nya itu. Dan bertakwalah kepada Allah serta ketahuilah bahwasanya Allah Maha Mengetahui segala sesuatu". (QS: Al-Baqarah: 231)

\footnotetext{
${ }^{30}$ Ibid, hlm. 206

${ }^{31}$ Qs. al-Baqarah (2):231.
} 


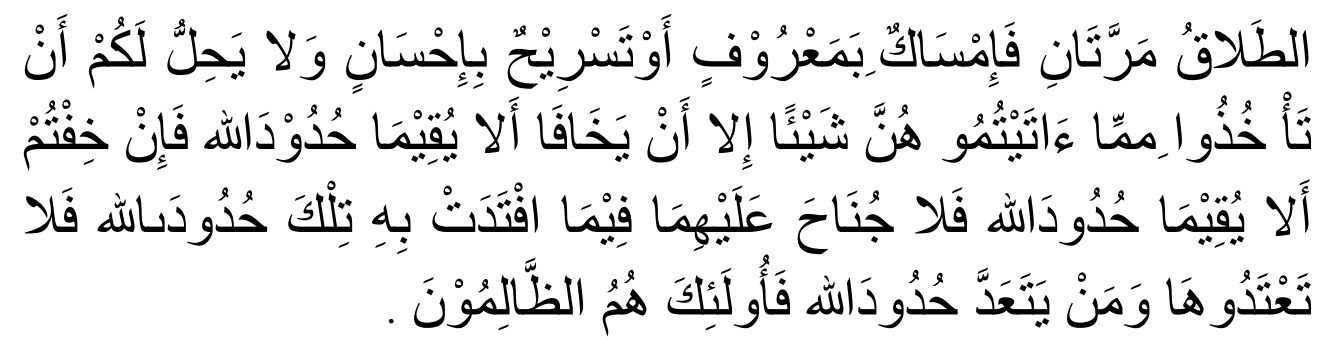

Artinya: "Talak (yang dapat dirujuki) adalah dua kali. Setelah itu boleh rujuk kembali dengan cara yang ma'ruf atau menceraikannya dengan cara yang baik. Tidak halal bagimu mengambil kembali sesuatu yang telah kamu berikan kepada mereka, kecuali kalau keduanya khawatir tidak dapat menjalankan hukum-hukum Allah. Jika kamu khawatir bahwa keduannya tidak dapat menjalankan hukum-hukum Allah, maka tidak ada dosa atas keduanya tentang bayaran yang diberikan oleh isteri untuk menebus dirinya. Itulah hukum-hukum Allah, maka janganlah kamu melanggarnya. Barang siapa yang melanggar hukum-hukum Allah mereka itulah orang-orang yang zalim". ${ }^{32}$

Kata yang mengindikasikan adanya penganjuran perceraian harus dilakukan secara ma'ruf dan baik yang terdapat dalam ayat pertama adalah (أَوْ سَرِّحُو هُنَّ بِمَعْرُوْفٍ) yang artinya “atau ceraikanlah mereka dengan cara yang ma'ruf'. Sedangkan pada ayat keduanya terdapat pada kalimat (أَوْتَسْرِيْحُ ِِإِحْسَانِ) yang artinya “atau menceraikannya dengan cara yang baik".

Berdasarkan dua kalimat tersebut sudah dapat dipahami bahwa Islam sangat menganjurkan apabila jalan perceraian memang merupakan jalan yang terakhir, maka hendaknya dilakukan secara ma'ruf dan baik.

Walaupun Islam telah merekomendasikan perceraian sebagai jalan terakhir dan memberikannya labelisasi perkara yang halal akan tetapi hal tersebut sangat dibenci oleh Allah. Ada yang menyebutkan bahwa Takhta

\footnotetext{
${ }^{32}$ Qs. Al-Baqarah (2):229.
} 
Yang Maha Kuasa dan Pemurah bergoyang ketika pasangan suami isteri bercerai. ${ }^{33}$ Dalam konteks ke-Indonesian kata "talak" masyhur di terjemahkan kepada kata "perceraian".

Secara jelas talak dalam istilah agama Islam diartikan sebagai pelepasan ikatan perkawinan atau bubarnya hubungan perkawinan atau melepas tali perkawinan dan mengakhiri hubungan suami istri. ${ }^{34}$ Dalam Kompilasi Hukum Islam (KHI) sebagaimana yang dikutip oleh Moh. Idris Ramulyo, dikatakan bahwa talak adalah Ikrar suami di hadapan sidang Pengadilan Agama yang menjadi salah satu sebab putusnya perkawinan dengan cara sebagaimana diatur dalam Pasal 129, 130 dan $131 .^{35}$

Dalam dunia praktik di Pengadilan Agama sebagaimana juga dijelaskan dalam KHI Pasal 114, istilah perceraian dibagi dua yaitu perceraian yang dapat terjadi karena talak (cerai talak) yaitu perceraian yang dimohonkan oleh suami terhadap isterinya dan perceraian yang disebabkan oleh gugatan perceraian (gugat cerai) yaitu perceraian yang diajukan ke Pengadilan Agama oleh pihak isteri terhadap suaminya.

b. Alasan Perceraian

Seorang suami yang akan menjatuhkan talak kepada isterinya atau isteri yang akan menggugat cerai suaminya harus mengajukan permohonan/gugatan baik lisan maupun tertulis kepada Pengadilan Agama yang mewilayahi tempat tinggal isterinya/suaminya disertai dengan alas an, serta meminta agar diadakan sidang untuk keperluan itu. Pengadilan Agama dapat mengabulkan atau menolak permohonan/gugatan tersebut, dan terhadap keputusan tersebut dapat diminta upaya hukum banding dan

${ }^{33}$ Hedaya Hartford, Merancang dan Memelihara Perkahwinan Dalam Islam Memulakan dengan Langkah Kanan (Selangor: Blue Nile Publishing, 2002), hlm. 145

${ }^{34}$ Abd. Rahman Ghazaly, Fiqh Munakahat (Jakarta: Prenada Media 2003), hlm.191-192.

${ }^{35}$ M. Idris Ramulyo, Hukum Perkawinan Islam: Suatu Analisis dari Undang-undang No. 1 Tahun 1974 dan Kompilasi Hukum Islam (Jakarta: Bumi Aksara, 2004),153. Lihat juga Amiur Nuruddin dan Azhari Akmal Tarigan, Hukum Perdata Islam di Indonesia; Studi Kritis Perkembangan Hukum Islam dari Fikih, UU No. 1/1974 sampai KHI., hlm. 220 
kasasi. Adapun alasan perceraian yang dibenarkan oleh hukum adalah antara lain $:^{36}$

1) Salah satu pihak berbuat zina atau menjadi pemabuk, pemadat, penjudi dan lain sebagainya yang sukar disembuhkan.

2) Salah satu pihak meninggalkan pihak lain selama 2 (dua) tahun berturut-turut tanpa izin pihak yang lain dan tanpa alasan yang sah atau karena hal-hal di luar kemampuannya.

3) Salah satu pihak mendapat hukuman penjara 5 (lima) tahun atau hukuman yang lebih berat setelah perkawinan berlangsung.

4) Salah satu pihak mendapat cacat badan atau penyakit dengan akibat tidak dapat menjalankan kewajiban sebagai suami/isteri.

5) Antara suami dan isteri terus menerus terjadi perselisihan dan pertengkaran dan tidak ada harapan akan hidup lagi dalam rumah tangga.

Dalam Kompilasi Hukum Islam alasan perceraian ini ditambah 3 (tiga) alasan sehingga menjadi 8 (delapan) alasan yaitu peralihan agama atau murtad yang menyebabkan terjadinya ketidakrukunan dalam rumah tangga, suami melanggar taklik-talak dan salah satu pihak melakukan kekejaman atau penganiayaan berat yang membahayakan pihak yang lain. ${ }^{37}$ Alasan di atas adalah alasan yang meliputi cerai talak maupun cerai gugat.

\section{Konsep Dasar Upaya Hukum Verzet}

a. Pengertian

Dalam dunia peradilan, sangat jarang diketemukan rasa puas diantara para pihak yang bersengketa terhadap apa yang telah menjadi keputusan pengadilan, hal ini sangat wajar karena menyangkut hak mereka

\footnotetext{
${ }^{36}$ Lihat Pasal 19 Peraturan Pemerintah RI. No. 9 Tahun 1975 Tentang Pelaksanaan Undangundang Nomor 1 Tahun 1974 Tentang Perkawinan.

${ }^{37}$ Lihat Pasal 116 Kompilasi Hukum Islam atau lihat M. Idris Ramulyo,,hlm. 153
} 
untuk mendapatkan keadilan, sehingga tidak heran jika mereka memperjuangkannya dengan berbagai sarana dan upaya. Sarana dan upaya yang mereka tempuh disebut dengan upaya hukum. Upaya hukum adalah suatu usaha bagi setiap pribadi atau badan hukum yang merasa dirugikan haknya atas kepentingannya untuk memperoleh keadilan dan perlindungan hukum, menurut cara-cara yang ditetapkan dalam Undang-undang. ${ }^{38}$ Adapun macam-macam upaya hukum tersebut sangat beraneka ragam, salah satunya upaya hukum tersebut dikenal dengan sebutan verzet.

Adapun pengertian Verzet adalah upaya hukum biasa yang dilakukan oleh pencari keadilan terhadap putusan Pengadilan Agama yang berupa putusan verstek. Putusan Verstek adalah putusan yang dijatuhkan pengadilan sebagai akibat dari ketidak hadiran tergugat atau termohon selama pemeriksaan perkara meskipun telah di panggil secara resmi dan patut, sedang penggugat atau pemohon hadir dan memohon putusan. ${ }^{39}$

Dalam bukunya A. Roihan Rasyid disebutkan bahwa verzet adalah perlawanan terhadap putusan verstek yang dijatuhkan oleh Pengadilan tingkat pertama, yang diajukan oleh tergugat yang diputus secara verstek tersebut dalam waktu tertentu yang diajukan ke Pengadilan Agama yang memutus perkara tersebut. ${ }^{40}$

b. Landasan Yuridis Upaya Hukum Verzet terhadap Putusan Verstek

Adapun yang menjadi landasan yuridis adanya perlawanan (verzet) dari pihak pencari keadilan yang tidak hadir dalam persidangan dan pembacaan putusan Pengadilan Agama (verstek) adalah Pasal 129 ayat (1) HIR yang ditegaskan bahwa "Tergugat yang dihukum sedang ia tidak

${ }^{38}$ Mukti Arto, hlm. 279.

${ }^{39} \mathrm{Ibid}, \mathrm{hlm} .256$. 1995), hlm. 227.

${ }^{40}$ A. Roihan Rasyid, Hukum Acara Peradilan Agama (Jakarta: PT Raja Grafindo Persada, 
hadir (verstek) dan tidak menerima putusan itu, dapat mengajukan perlawanan atas putusan tersebut". 41

c. Alasan-alasan Pengajuan Verzet

Setiap upaya hukum tentunya memiliki alasan dan dasar atau faktor yang melatarbelakanginya sebagai modal untuk menempuh ke langkah berikutnya dalam rangka mempertahankan apa yang menjadi hak bagi para pihak pencari keadilan serta terlepas dari penilaian hakim apakah alasan tersebut rasional dan benar atau irrasional dan tidak benar.

Dalam pengajuan upaya hukum verzet yang dilakukan oleh pelawan pada umumnya dilator belakangi oleh beberapa faktor diantaranya: ${ }^{42}$

1) Tergugat/termohon tidak merasa dipanggil oleh pengadilan karena pihak kelurahan yang dimintakan bantuan untuk menyampaikan panggilan tidak dilaksanakan dengan baik, tetapi jika panggilan lewat kelurahan telah dilaksanakan, tetapi pihak yang dipanggil tidak di tempat, maka diberatkan oleh hukum acara yang berlaku.

2) Tergugat sebagai suami dari penggugat merasa bahwa selama ini tidak hadir dan tidak menjatuhkan talaknya, perceraian tidak mungkin terjadi. Hal ini dilatar belakangi karena oleh kesalahpahaman bahwa talak hanya milik suami.

3) Tergugat/termohon sengaja tidak datang dengan perhitungan bahwa perceraian tidak mungkin terjadi jika salah satu pihak tidak hadir di persidangan.

\section{d. Prosedur Pemeriksaan Perkara Verzet}

Prosedur pemeriksaan perkara dalam verzet sebanarnya tidak terlalu berbeda dengan pemeriksaan perkara biasa. Dalam pemeriksaan perkara verzet tetap menggunakan nomor perkara asal. Penggugat/termohon

\footnotetext{
${ }^{41}$ R. Soesilo, hlm.. 86.

${ }^{42}$ Ropaun Rambe dan A. Mukri Agafi, Hir/Rbg Dengan Penjelasan.hlm., 248.
} 
didudukkan sebagai terlawan, sementara tergugat/termohon didudukkan sebagai pelawan. Adapun secara hirarkis tahap dan prosedur pemeriksaan perkara verzet dapat dilakukan dengan tahapan-tahapan berikut :

1) Pengecekan Identitas Pihak Berperkara

Pengecekan identitas dilakukan untuk mencocokkan identitas yang telah tertuang dalam putusan verstek yang tidak mustahil dalam identitas terjadi kekeliruan, baik nama jelas, umur, agama, pekerjaan maupun tempat tinggal.

2) Upaya Damai

Upaya damai dilakukan oleh majelis hakim sebagaimana upaya damai yang seharusnya dilakukan pada pemeriksaan perkara. Karenanya jika upaya damai berhasil, maka perkara dianggap dicabut dalam hal sengketa perkawinan atau perceraian, dan dalam sengketa lain dapat berupa putusan perdamaian yang didasarkan pada hasil perdamaian antara kedua belah pihak yang berperkara.

3) Pembacaan Surat Perlawanan

Sebelum dibacakan surat perlawanan, terlebih dahulu dibacakan putusan verstek terutama tentang amar putusan verstek tersebut dan juga dibacakan surat pemberitahuan amar putusan kepada tergugat/termohon sebagai pelawan dalam perkara verzet

4) Jawaban Perlawanan

Pihak Penggugat/ termohon sebagai terlawan mempunyai hak untuk menanggapi surat perlawanan pelawan.

5) Tahap Pembuktian

Pada tahap pembuktian ini, dipisahkan antara perkara verzet dalam sengketa perkawinan dengan sengketa diluar perkawinan. Dalam sengketa perkawinan, pada umumnya pembuktian telah dilakukan pada pemeriksaan yang menghasilkan putusan 
verstek. Dalam kondisi seperti ini, majelis cukup membacakan hasil pemeriksaan pembuktian tersebut, baik pembuktian berupa surat maupun saksi. Jika perkara sengketa lain di luar perkawinan, maka pembuktian dilakukan sebagaimana pemeriksaan pembuktian pada umumnya.

6) Pembacaan Putusan

Tahap pembacaan putusan tidak berbeda jauh dengan pembacaan putusan pada perkara di luar verzet. Dalam arti, putusan dibacakan dalam sidang terbuka untuk menjelaskan kepada para pihak yang berperkara bahwa mereka dapat melakukan upaya hukum banding jika mereka menerima atau merasa keberatan atas putusan verzet tersebut.

Dalam dunia peradilan, upaya hukum memang legal untuk dijalankan dan digunakan karena menyangkut rasa keadilan yang didapat oleh para pencari keadilan, namun disamping itu juga upaya hukum dapat dijadikan kedok oleh oknum pencari keadilan untuk menunda-nunda eksekusi demi kepentingan yang selama ini menjadi misinya. Pemilahan antara pengguna upaya hukum yang sebenarnya dan yang hanya bertujuan untuk menunda-nunda eksekusi adalah sangat sulit. Apabila hal ini benarbenar terjadi, maka penumpukan perkara di tingkat kasasi adalah merupakan pemandangan yang tidak bisa dipungkiri.

Solusi yang dapat memungkinkan untuk meminimalisir penumpukan perkara di tingkat kasasi, tingkat banding dan tingkat pertama adalah pemberdayaan sistem penyelesaian dengan cara Alternative Dispute Resolution (ADR). Di samping sebagai solusi meminimalisir penumpukan perkara, Alternative Dispute Resolution juga menawarkan penyelesaian perkara yang bersifat win-win solution, biaya ringan, cepat dan menghilangkan rasa dendam yang mungkin muncul di kemudian hari. 


\section{Konsep Dasar Alternative Dispute Resolution (ADR)}

Konseptualisasi ADR muncul dan digunakan pertama kali di Amerika Serikat pada tahun 1976, di mana Chief Justise Warren Burger memprakarsai sebuah konferensi yang menanyakan kembali efektifitas administrasi pengadilan. Secara resmi istilah ADR diadopsi oleh American Bar Association (ABA) pada tahun 1976. Kemudian pada tahun-tahun berikutnya pendidikan tinggi hukum di Amerika Serikat memasukkan ADR di dalam kurikulum perkuliahannya. $^{43}$

Konsep Alternative Dispute Resolution ini merupakan jawaban atas ketidakpuasan yang muncul di masyarakat Amerika Serikat terhadap sistem pengadilan mereka. Ketidakpuasan tersebut bersumber pada persoalan waktu yang dibutuhkan sangat lama dan biaya mahal, serta diragukan kemampuannya menyelesaikan secara memuaskan terhadap kasus-kasus yang bersifat rumit. $^{44}$

Alternative Dispute Resolution atau ADR dalam praktek di Indonesia masih bisa dikatakan relatif baru, meskipun prinsip-prinsipnya telah lama dijalankan oleh komunitas adat di Indonesia dalam menyelesaikan sengketa. ADR merupakan istilah asing yang perlu dicarikan padanannya dalam bahasa Indonesia. Berbagai istilah dalam bahasa Indonesia telah diperkenalkan dalam berbagai forum oleh berbagai pihak, seperti pilihan penyelesaian sengketa (PPS), mekanisme alternatif penyelesaian sengketa (MPS), pilihan penyelesaian sengketa di luar pengadilan, dan mekanisme penyelesaian sengketa yang kooperatif. ${ }^{45}$

43 Mulyani Zulaeha, "Pola Penyelesaian Sengketa Keperdataan di Luar Pengadilan; Perbandingan Alternative Dispute Resolution dan Lembaga Arbitrase," Syari'ah Jurnal Hukum dan pemikiran, 2 (Juli-Desember, 2003), hlm. 188-189.

${ }^{44}$ Ibid, hlm. 189.

${ }^{45}$ Rahmat Syafa'at, Advokasi dan Pilihan Penyelesaian Sengketa; Latar Belakang, Konsep dan Implementasinya (Malang: Agritek YPN Malang, 2006), hlm. 53. 
ADR adalah salah satu mekanisme penyelesaian sengketa non litigasi dengan mempertimbangkan segala bentuk efisiensinya dan untuk tujuan masa yang akan datang sekaligus menguntungkan bagi para pihak. ${ }^{46}$

Seperti telah diuraikan di atas bahwa ADR lahir dari rahim reaksi ketidakpuasan terhadap penyelesaian sengketa melalui proses litigasi. Melalui jalur ini dianggap membuang-buang waktu dan memerlukan biaya yang tidak sedikit dimana masing-masing pihak yang berperkara harus saling berhadapan dan yang paling penting adalah putusan akhirnya yang akan memenangkan salah satu pihak yang dapat membuktikan apa yang menjadi dalilnya.

Alternative Dispute Resolution (ADR) merupakan langkah alternatif terhadap pemecahan suatu sengketa yang masih berada dalam koridor atau norma-norma hukum yang ada, karena solusi yang ditawarkannya bukan merupakan upaya sogok-menyogok terhadap perangkat penegakan hukum seperti halnya praktik mafia peradilan yang biasa terjadi sehari-hari di dunia peradilan. $^{47}$ Praktik mafia peradilan banyak merugikan pihak yang dikalahkan, karena selama ini pihak yang dikalahkan adalah mereka yang lemah dan tidak punya uang (kekuatan/kekuasaan). Hal ini berbeda jauh dengan bentuk penyelesaian sengketa dengan cara ADR yang lebih mengedepankan prinsip sama-sama menang bagi para pihak dan tidak ada yang dikalahkan atau dimenangkan secara mutlak. Sehingga dari sini ADR lebih menarik minat dan perhatian bagi masyarakat pencari keadilan.

${ }^{46}$ Ada juga yang memahami ADR sebagai teknik atau mekanisme penyelesaian sengketa yang dikembangkan sebagai alternative dari mekanisme penyelesaian sengketa yang lebih dahulu dikenal yaitu litigasi (pengadilan), lihat Mulyani Zulaeha, Syari'ah Jurnal Hukum dan pemikiran ,hlm. 188.

${ }^{47}$ Henny Mono, Praktek Berperkara Pidana (Malang: H-Mono Law Firm, 2004), hlm. 30- 
a. Macam-macam ADR

1) Mediasi

Dalam Kamus Besar Bahasa Indonesia disebutkan bahwa yang dimaksud dengan mediasi adalah proses pengikutsertaan pihak ketiga dalam menyelesaikan suatu perselisihan sebagai nasehat. ${ }^{48}$ Banyak pengertian mediasi yang dikonsepkan oleh para pakar yang antara satu dengan yang lainnya berbeda menurut versi masing-masing diantaranya ada yang menformulasikan bahwa mediasi dapat diartikan secara luas dan juga dapat diartikan secara sempit. Secara luas mediasi diartikan sebagai penyelesaian sengketa yang dilaksanakan baik oleh pihak ketiga, diluar sistem pengadilan maupun di dalam pengadilan. $^{49}$

Senada dengan pengertian di atas pengertian yang diusung oleh $\mathrm{M}$. Yahya Harahap yang mengatakan bahwa mediasi adalah proses penyelesaian sengketa di pengadilan melalui perundingan antara pihak yang berperkara, perundingan tersebut dibantu oleh seorang mediator yang berkedudukan sebagai pihak ketiga yang netral dan berfungsi sebagai pembantu dalam mencari barbagai kemungkinan atau alternatif penyelesaian sengketa yang terbaik dan saling menguntungkan bagi para pihak. ${ }^{50}$

${ }^{48}$ Lihat Kamus Besar Bahasa Indonesia, hlm. 640

49 Soerharto "Pengarahan Dalam Rangka Pelatihan Mediator Dalam Menyambut Penerapan”Perma Court Annexed Mediation Di Pengadilan Di Indonesia, Mediasi dan Perdamaian ( Jakarta: Mahkamah Agung Republik Indonesia 2002), hlm. 11

${ }^{50}$ Yahya Harahap, Hukum Acara Perdata (Jakarta: Sinar Grafika, 2005), hlm. 224. masih banyak lagi pengertian mediasi yang dikonsepkan oleh para ahli seperti 1) Hadimulyo yang mendefinisikan mediasi sebagai bantuan dari pihak ketiga dalam suatu proses negosiasi, namun pihak ketiga (mediator) tersebut tidak ikut serta mengambil keputusan, lihat Hadimulyo, Mempertimbangkan $A D R$,h. 35. 2) Rahmad Syafaat mendefinisikan mediasi sebagai proses negosiasi pemecahan konflik atau sengketa di mana pihak luar atau pihak ketiga yang tidak memihak bekerjasama dengan pihak yang bersengketa untuk membantu memperoleh kesepakatan perjanjian dengan memuaskan, mediasi dalam bahasa Inggris disebut mediation adalah penyelesaian sengketa dengan menengahi, lihat Rahmad Syafaat, Advokasi dan Pilihan Penyelesaian Sengketa h.57. 3) bandingkan dengan Abdul Manan mengatakan bahwa mediasi adalah suatu proses di mana para pihak dengan bantuan seseorang 
Mediasi pada dasarnya adalah negosiasi yang melibatkan pihak ketiga yang memiliki keahlian mengenai prosedur mediasi yang efektif, dan dapat membantu dalam situsiasi konflik untuk mengkoordinasi aktifitas mereka sehingga lebih efektif dalam proses tawar-menawar bila tidak ada negosiasi, maka mediasi tidak ada. ${ }^{51}$

Berdasarkan berbagai formulasi pengertian mediasi di atas dapat ditarik kesimpulan sementara bahwa mediasi adalah proses penyelesaian perkara melalui jalur perundingan yang dipandu oleh seorang mediator yang netral dengan tujuan untuk mencapai kesepakatan yang diterima oleh para pihak yang bersengketa guna mengakhiri perkara.

Dalam mediasi setidaknya terdapat beberapa ciri pokok diantaranya, adanya proses atau metode, terdapat beberapa pihak yang relevan atau pihak perwakilan dan dibantu pihak ketiga sebagai seorang mediator, berusaha melalui diskusi dan perundingan untuk mendapatkan keputusan yang dapat disetujui para pihak.

Mediasi ini secara khusus diatur lebih lanjut di dalam Peraturan Mahkmah Agung Nomor 2 Tahun 2003 tentang Prosedur Mediasi Di Pengadilan yang terdiri dari 18 Pasal yang di dalamnya di paparkan mengenai prosedur-prosedur yang harus dilalui dalam proses mediasi tersebut.

2) Negosiasi

Kata negosiasi berasal dari "negotiation" dalam bahasa Inggris yang diterjemahkan ke dalam bahasa Indonesia dengan kata "berunding" atau "bermusyawarah". Orang yang mengadakan perundingan disebut

atau beberapa orang secara sistematis menyelesaikan permasalahan yang disengketakan untuk mencari alternative dan mencapai permasalahan yang mengakomodasi kebutuhan mereka, lihat Abdul Manan, Penerapam Hukum Acara Perdata di Lingkungan Peradilan Agama, hlm. 175

51 Said Faisal, Pengantar Mediasi; Bagaimana Suatu Sengketa Diselesaikan (Jakarta: Mahkamah Agung Republik Indonesia 2002), hlm. 61 
dengan negosiator. Secara global negosiasi dapat diartikan sebagai suatu upaya penyelesaian sengketa para pihak tanpa melalui proses litigasi dengan tujuan untuk mencapai kesepakatan bersama atas dasar kerja sama yang lebih harmonis dan kreatif. $^{52}$ Disini para pihak bertemu dan berhadapan langsung secara seksama dalam mendiskusikan permasalahan yang mereka hadapi dengan cara kooperatif dan saling terbuka satu sama lain.

Ada juga yang mendefinisikan negosiasi sebagai komunikasi dua arah yang dirancang untuk mencapai kesepakatan pada saat kedua belah pihak memiliki kepentingan yang sama maupun yang berbeda, tanpa keterlibatan pihak ketiga sebagai penengah, baik pihak ketiga yang tidak berwenang mengambil keputusan (mediator) maupun pihak ketiga yang berwenang mengambil keputusan (ajudikator). ${ }^{53}$

Terdapat beberapa kondisi atau persyaratan yang dapat mempengaruhi berhasil tidaknya suatu negosiasi, yaitu: kejelasan para pihak yang bersedia bernegosiasi, interdependesi, kesediaan untuk bernegosiasi, sarana dan kemampuan untuk saling mempengaruhi, kesepakatan untuk menentukan suatu isu dan beberapa kepentingan, kesediaan untuk menyelesaikan, hasil yang belum bisa diprediksi, adanya suatu keperluan yang mendesak dan harus diselesaikan, tidak ada hambatan psikologis yang berarti untuk dicapainya kesepakatan, adanya kepentingan dan isu yang dapat di negosiasikan, adanya wewenang para pihak untuk memutuskan, kesediaan untuk saling

${ }^{52}$ Dalam pengertian yang lain disebutkan bahwa negosiasi adalah suatu proses dimana para pihak yang berselisih atau perwakilannya berusaha menyelesaikan permasalahan melalui diskusi, edukasi, pendekatan persuasive dan proses tawar-manawar, dan berjalan tanpa dibantu pihak ketiga yang netral, Abdul Manan, Penerapam Hukum Acara Perdata h.171. lihat Said Faisal, Pengantar Mediasi; Bagaimana Suatu Sengketa Diselesaikan, hlm.156.

${ }^{53}$ Mas Achmad Santoso dan Wiwiek Awiati "Negosiasi dan Mediasi; Bagaimana Suatu Sengketa Diselesaikan, Mediasi dan Perdamaian (Jakarta: Mahkamah Agung Republik Indonesia 2002), hlm. 29. 
memberi dan menerima, kesepakatan yang diambil cukup rasional dan dapat dilaksanakan, adanya faktor-faktor luar yang mendorong dan memungkinkan tercapainya kesepakatan, dan tersedianya sumber daya (dana, waktu dan lain-lain) untuk melakukan negosiasi. ${ }^{54}$

3) Konsiliasi

Konsiliasi adalah usaha yang dilakukan pihak ketiga yang bersifat netral, untuk berkomunikasi dengan kelompok-kelompok yang bersengketa secara terpisah, dengan tujuan untuk mengurangi ketegangan dan mengusahakan ke arah tercapainya persetujuan untuk berlangsungnya suatu proses penyelesaian perkara. ${ }^{55}$

Menurut Abdul Manan konsiliasi dapat diartikan sebagai upaya membawa para pihak-pihak yang bersengketa untuk menyelesaikan permasalahan diantara kedua belah pihak secara negosiasi. ${ }^{56}$

Menurut Hadimulyo strategi ini lazim dilakukan oleh pihak yang mendamaikan para pihak yang terlibat konflik yang tidak mungkin atau sulit menyelesaikannya dengan saling berhadapan dalam meja bundar perundingan. Konsiliasi mensyaratkan adanya pihak ketiga yang bisa diterima oleh para pihak yang bersengketa.

4) Konsultasi.

Konsultasi adalah pertemuan dua pihak atau lebih untuk membahas masalah-masalah yang dianggap penting untuk dapat dicarikan pemecahannya bersama. Pertemuan konsultasi biasanya digunakan para pihak kepada seseorang atau badan yang dinilai memiliki kekuasaan otoritatif untuk memberikan pertimbangan, saran, atau usulan yang bertujuan untuk menyelesaikan masalah yang disengketakan yang ada secara lebih memuaskan.

${ }^{54}$ Hadimulyo, Mempertimbangkan ADR , hlm. 34-35.

${ }^{55} \mathrm{Ibid}, \mathrm{hlm} .31-32$.

56 Abdul Manan, Op.Cit., hlm.180. Pengertian konsiliasi sangat beragam redaksinya, namun secara substansial tidak ada perbedaan yang signifikan. 
Konsultasi bisa berupa forum untuk saling bertukar informasi, bertukar pengalaman, dan bermuara pada pertemuan pengambilan keputusan. $^{57}$

b. Landasan Yuridis Alternative Dispute Resolution (ADR)

1) Pasal 130 HIR jo Pasal 154 R.Bg disebutkan bahwa "Jika pada hari yang telah ditentukan itu, kedua belah pihak datang, maka, pengadilan negeri dengan pertolongan ketua mencoba untuk memperdamaikan mereka". 58

2) Pasal 1338 KUHPdt disebutkan bahwa "Semua Perjanjian yang dibuat secara sah berlaku sebagai Undang-undang bagi mereka yang membuatnya". 59

3) Undang-undang Nomor 14 tahun 1970 Tentang Ketentuan-ketentuan Pokok Kekuasaan Kehakiman, dalam Pasal 3 dan Pasal 14 jo Undangundang Nomor 4 Tahun 2004 Tentang Kekuasaan Kehakiman, dalam Pasal 16 ayat (2) disebutkan bahwa "Ketentuan sebagaimana dimaksud pada ayat (1) tidak menutup usaha penyelesaian perkara perdata secara perdamaian".

4) Undang-undang Nomor 30 tahun 1999 tentang Arbitrase dan Alternatif Penyelesaian Sengketa, dalam Pasal 6 ayat (1) disebutkan bahwa "Sengketa atau beda pendapat perdata dapat diselesaikan oleh para pihak melalui alternatif penyelesaian sengketa yang didasarkan pada i'tikad baik dengan mengesampingkan penyelesaian secara litigasi di Pengadilan Negeri", 60

\footnotetext{
${ }^{57}$ Ibid, hlm. 36

${ }^{58}$ Himpunan Peraturan Perundang-undangan Dalam Lingkungan Peradilan Agama, hlm.
} 65

${ }^{59}$ Subekti dan R. Tjitrosudibio, Kitab Undang-undang Hukum Perdata (Jakarta: Pradnya Paramita, 2001), hlm. 342

\footnotetext{
${ }^{60}$ Kapita Selekta beberapa Materi Hukum, Pusdiklat Mahkamah Agung 2002, hlm. 115.
} 


\section{PENUTUP}

\section{Kesimpulan}

Adapun faktor-faktor yang mendukung usaha-usaha penerapan ADR dalam proses penyelesaian perkara verzet, yaitu adanya i'tikad baik dari semua unsur Penegak Hukum, adanya kemauan dari para pihak yang berperkara untuk menyelesaikan perkaranya secara baik-baik, saling puas dan sama-sama menang, adanya sifat fleksibelitas dari sistem ADR itu sendiri yang dapat diatur dan dipilih oleh para pihak yang bersengketa tanpa harus mengikuti prosedur formal yang ada, adanya kesadaran dari para pihak untuk mengikutsertakan pihak ketiga (hakam/fasilitator), kedudukan hakam akan lebih baik jika dipegang oleh kerabat, hakam harus orang yang kridibel dan tahu tentang perkara yang dihadapi kedua belah pihak, serta kedua belah pihak mempunyai pandangan kedepan dalam menyelesaikan sengketanya secara baik-baik tanpa harus memunculkan sengketa baru lagi yang malah penyelesaiannya bisa berkepanjangan, serta berdasarkan kesepakatan yang mereka buat adalah untuk kepuasaan kedua belah pihak serta menghindari kemungkinan dendam yang dipendam dan muncul dikemudian hari.

Sedangkan faktor penghambat penerapan ADR dalam penyelesaikan sengketa, yaitu tidak adanya i'tikad baik dari semua unsur Penegak Hukum, tidak adanya i'tikad baik dari kedua belah pihak untuk menyelesaikan sengketanya secara baik-baik dan saling menjatuhkan antara yang satu dengan yang lain, adanya salah satu pihak yang tidak menginginkan penyelesaian perkaranya secara ADR serta menyelesaikannya secara baik-baik. salah satu pihak sering mengulur-ngulur waktu dan tidak datang dalam perundingan, pihak penengah dari pihak-pihak yang bersengketa kurang cakap dan kurang memahami permasalahan yang disengketakan serta tidak adanya kesadaran dari kedua belah pihak untuk mengikutsertakan pihak ketiga dalam penyelesaian perkaranya. 


\section{DAFTAR PUSTAKA}

\section{A. Literatur}

Amiur, Nuruddin, an Azhari Akmal Tarigan, Hukum Perdata Islam di Indonesia; Studi Kritis Perkembangan Hukum Islam dari Fikih, UU No. 1/1974 sampai KHI, Jakarta: Prenada Media, 2004.

Manan, Abdul Manan, Penerapan Hukum Acara Perdata di Lingkungan Peradilan Agama, Jakarta: : Kencana, 2005.

Bisri, Hasan, Peradilan Islam dalam Tatanan Masyarakat Indonesia, Bandung: PT. Remaja Rosdakarya, 1997.

Ghazaly, Abd. Rahman, Fiqh Munakahat, Jakarta: Prenada Media 2003.

Hadimulyo, Mempertimbangkan ADR: Kajian Alternatif Penyelesaian Sengketa di Luar Pengadilan, Jakarta: Elsam, 1997.

Harahap , M, Yahya, Kedudukan Kewenangan dan Acara Peradilan Agama ,Jakarta: Sinar Grafika, 2003.

Hartford, Hedaya, Merancang dan Memelihara Perkahwinan Dalam Islam Memulakan dengan Langkah Kanan Selangor: Blue Nile Publishing, 2002.

Mono, Henny, Praktek Berperkara Pidana, Malang: H-Mono Law Firm, 2004.

Ramulyo , M. Idris, Hukum Perkawinan Islam: Suatu Analisis Dari Undangundang No. 1 Tahun 1974 dan Kompilasi Hukum Islam, Jakarta: Bumi Aksara, 2004.

Rasyid . A. Roihan, Hukum Acara Peradilan Agama, Jakarta: PT Raja Grafindo Persada, 1995.

Santoso , Mas Achmad dan Wiwiek Awiati "Negosiasi dan Mediasi; Bagaimana Suatu Sengketa Diselesaikan, Mediasi dan Perdamaian Jakarta: Mahkamah Agung Republik Indonesia 2002.

Subekti dan R. Tjitrosudibio, Kitab Undang-undang Hukum Perdata, Jakarta: Pradnya Paramita, 2001 
Widjaja ,Gunawan, Seri Hukum Bisnis:Alternatif Penyelesaian Sengketa, Jakarta: PT. Raja Grafindo Persada, 2005.

Zulaeha, Mulyani "Pola Penyelesaian Sengketa Keperdataan di Luar Pengadilan; Perbandingan Alternative Dispute Resolution dan Lembaga Arbitrase," Syari'ah Jurnal Hukum dan pemikiran, 2 Juli-Desember, 2003.

\section{B. Lain-lain}

Al-Qur'an dan Terjemahnya 